\title{
General surgery practice under the COVID-19 pandemic: The experience of a pandemic hospital in Istanbul
}

(1) Yasin Tosun, M.D., () Kenan Çetin, M.D.

Department of General Surgery, İstanbul Kartal Dr. Lütfi Kırdar City Hospital, İstanbul-Turkey

\begin{abstract}
BACKGROUND: Although elective operations in general surgery clinics were postponed during the pandemic, non-deferrable operations such as emergency trauma, acute abdominal, and cancer surgeries continued. We aimed to present emergency and non-deferrable elective surgery cases in our hospital's general surgery clinic during the pandemic, to identify the general surgery patients that pose the greatest risk for healthcare workers who served these patients, and to share our experience in these situations.
\end{abstract}

METHODS: The study was designed as a retrospective cohort study. The study included patients admitted for emergency and non-deferrable elective surgeries in Kartal Dr. Lutfi Kirdar City Hospital in Istanbul between March 10, 2020, and May 23, 2020. The patients were tested before the operation for severe acute respiratory syndrome-related coronavirus 2 (SARS-CoV-2) infection. They were also routinely checked for fever and coronavirus disease 2019 (COVID-19) symptoms during dressing changes and outpatient follow-up visits after discharge as well as through the national health monitoring system (e-nabız) whether the patients were diagnosed with COVID-19 within the 15 days of discharge. Patients who tested positive in the reverse transcription-polymerase chain reaction (RT-PCR) tests in the first 15 days after discharge or had infiltration in thorax tomography were considered suspicious in terms of hospital transmission.

RESULTS: During the COVID-19 pandemic period between March 10, 2020, and May 23, 2020, a total of 195 patients were operated on. Of these, 96 (49.2\%) were operated due to emergencies, and 99 (50.8\%) were non-deferrable elective surgeries. At the time of admission, 13 patients were diagnosed with COVID-I9 through RT-PCR and thorax tomography findings. A higher proportion of the patients with COVID-19 ( $n=12,92.3 \%)$ were found to be operated for emergencies. Three patients with COVID-19 died on the Ist postoperative day. Mortality was significantly higher in this group than in those who tested negative $(n=3,23.1 \%$ vs. $n=8,4.4 \%)$. During the study, none of the healthcare workers in our clinic developed COVID-I 9 symptoms. Three patients who had elective surgery were found to be SARS-CoV-2 (+) in the follow-up period after discharge.

CONCLUSION: Maintaining functional surgery departments under challenging times, such as a pandemic, will continue to be an important aspect of health systems. We believe that the results of this study will help reduce in-hospital transmission, help prevent disease transmission to healthcare personnel, and allow the members of the surgical teams to know in which patient group they will be at higher risk of infection during the operation.

Keywords: Coronavirus disease 2019; emergency operations; general surgery; severe acute respiratory syndrome-related coronavirus 2.

\section{INTRODUCTION}

The new coronavirus disease 2019 (COVID-19) spread rapidly throughout the world after its first appearance in Wuhan, China, in late December 2019 and was declared an epidemic by the World Health Organization on March II, 2020. ${ }^{[1,2]}$ The first case of COVID-19 in Turkey was identified March 10, 2020. On March 17, 2020, the Ministry of Health issued a memorandum for the postponement of all non-emergency surgical procedures to reduce the workload of hospitals and healthcare personnel in Turkey. In addition, within the scope of the measures taken to slow down the pandemic in Turkey,

Cite this article as: Tosun Y, Çetin K. General surgery practice under the COVID-19 pandemic: The experience of a pandemic hospital in Istanbul. Ulus Travma Acil Cerrahi Derg 2022;28:175-179.

Address for correspondence: Yasin Tosun, M.D.

İstanbul Kartal Dr. Lütfi Kırdar Şehir Hastanesi, Genel Cerrahi Kliniği, İstanbul, Turkey

Tel: +90 216 - 4583000 E-mail: yasintosun@gmail.com

Ulus Travma Acil Cerrahi Derg 2022;28(2):175-179 DOI: 10.14744/tjtes.2020.80025 Submitted: 18.07.2020 Accepted: 26.10.2020

Copyright 2022 Turkish Association of Trauma and Emergency Surgery 
lockdown measured were introduced for people aged 65 and over who were considered a high-risk group, and those aged 20 and under, who were considered potential spreaders of the infection.

Although elective operations in general surgery clinics were postponed during the pandemic, non-deferrable operations such as emergency trauma, acute abdominal, and cancer surgeries continued. Operating rooms are high-risk areas for airway transmission of infections, especially considering the large number of personnel, the risk of contamination, and the urgency of the procedures. ${ }^{[3]}$ In this process, guidelines were published for the protocols that surgeons should follow when approaching to and performing surgical procedures for the patients who tested positive for the disease agent, severe acute respiratory syndrome coronavirus 2 (SARS-CoV-2), were suspected of having the infection, or tested negative. ${ }^{[4-6]}$

In this study, we aimed to present emergency and non-deferrable elective surgery cases in our hospital's general surgery clinic during the pandemic, to identify the general surgery patients that pose the greatest risk for healthcare workers who served these patients during the pandemic, and to share our experience in these situations.

\section{MATERIALS AND METHODS}

\section{Study Design}

The study was designed as a retrospective cohort study. The study included patients admitted for emergency and non-deferrable elective surgeries in Kartal Dr. Lutfi Kirdar City Hospital in Istanbul between March 10, 2020, and May 23, 2020, the most intense initial period of the COVID-19 pandemic in Turkey. The study protocol was approved by the institutional review board (Approval number: 2020/5 I4/I8I/I).

\section{The Surgical Approach of Our Clinic during the COVID-19 Pandemic}

Before the operation, nasopharyngeal swab samples for SARS-CoV-2 reverse transcription-polymerase chain reaction (RT-PCR) tests were taken once from patients who would undergo emergency surgery and twice from those who would undergo non-deferrable elective surgeries. Each patient had thorax tomography before the operation.

The surgical team used personal protective equipment, N-95 mask, and protective glasses during the operation for patients who tested SARS-CoV-2 (+) or were strongly suspected of having COVID-19. The operating room was ventilated for 30 min and disinfected between two consecutive surgeries. For patients who tested SARS-CoV-2 (-), the surgical team used an N-95 mask and protective glasses during the operation. Each patient stayed in a separate single room in the post-operative period and was recommended to stay in preventive quarantine for 15 days after discharge.

\section{Inclusion and Exclusion Criteria}

All patients who had surgery in the general surgery clinic in this period were included in the study. Those who were under the age of 18, were operated in other surgical clinics, did not have an RT-PCR test before the operation, or did not have their follow-up at our hospital were excluded from the study.

\section{The Data}

The data were collected from patient epicrisis reports, nurse observation reports, and surgery reports. The groups were compared in terms of demographic characteristics, type of operation, SARS-CoV-2 test results, mortality, and the length of hospital and intensive care unit (ICU) stay.

\section{Follow-up}

The patients were routinely checked for fever and COVID-19 symptoms during dressing changes and outpatient follow-up visits after discharge. It was also checked through the national health monitoring system (e-nabız) whether the patients were diagnosed with COVID-19 in the 15 days after discharge. Patients who tested positive in the RT-PCR tests in the first 15 days after discharge or had infiltration in thorax tomography were considered suspicious in terms of hospital transmission.

\section{Data Analysis and Statistics}

The statistical analysis was done using IBM Statistical Package for the Social Sciences Statistics (version 24.0, IBM Corp., Armonk, NY, USA). Descriptive statistical methods (median, frequency, percent, minimum, and maximum) were used to evaluate the study data. Pearson Chi-square test was used to compare qualitative data, and Fisher's exact test was used when the sample sizes in sub-groups were small. The normal distribution of quantitative data was assessed by the Kolmogorov-Smirnov test and Shapiro-Wilk test. The quantitative data with non-normal distribution were compared using the Mann-Whitney $U$ test. For all analyses, a $p<0.05$ was considered for statistical significance.

\section{RESULTS}

During the COVID-19 pandemic period between March 10, 2020 , and May 23, 2020, a total of 195 patients were operated on. Of these, 96 (49.2\%) were operated due to emergencies, and 99 (50.8\%) were non-deferrable elective surgeries (Table I).

Of the patients in our cohort, 105 (53.8\%) were male, and 90 (46.2\%) were female; the median age was 50 years (range: 16-92). At the time of admission, 13 patients were diagnosed with COVID-19 through RT-PCR and thorax tomography findings. Of these patients, six (46.2\%) were female, and seven $(58.8 \%)$ were male. The median age was 50.5 years (range: 
Table I. The comparison of the characteristics of SARS-CoV-2 (+) and (-) patients

\begin{tabular}{|c|c|c|c|c|}
\hline & All patients, $n=195$ & SARS-CoV-2 (-), $n=182$ & SARS-CoV-2 (+), $n=13$ & $\mathbf{p}$ \\
\hline Age, years, median (range) & $50(16-92)$ & $50.5(16-92)$ & $37(18-82)$ & $0.880^{\mathrm{a}}$ \\
\hline Gender, n (\%) & & & & 1.000 \\
\hline Male & $105(53.8)$ & $98(53.8)$ & $7(58.8)$ & \\
\hline Female & $90(46.2)$ & $84(46.2)$ & $6(46.2)$ & \\
\hline Operation type, n (\%) & & & & $0.00 I^{b}$ \\
\hline Emergency operations & $96(49.2)$ & $84(46.2)$ & $12(92.3)$ & \\
\hline Non-deferrable elective & $99(50.8)$ & $98(53.8)$ & I (7.7) & \\
\hline ICU stay, n (\%) & $28(14.4)$ & $24(13.2)$ & $4(30.8)$ & $0.100^{b}$ \\
\hline Length of ICU stay, days, median (range) & $5.5(1-60)$ & $6(I-60)$ & $I(I-I)$ & \\
\hline Length of hospital stay, days, median (range) & $2(0-60)$ & $2(0-60)$ & $2(1-10)$ & $0.630^{\mathrm{a}}$ \\
\hline Mortality, n (\%) & II (4.2) & $8(4.4)$ & $3(23.1)$ & $0.030^{\mathrm{b}}$ \\
\hline
\end{tabular}

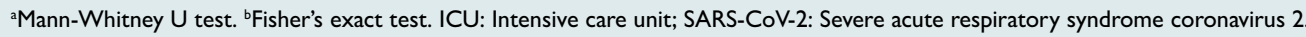

16-92) for those who tested negative and 37 years (range: 18-82) for those who tested positive. No significant difference was found between the patients who tested negative and positive in terms of age and gender $(p>0.05)$ (Table I).

A higher proportion of the patients with COVID-19 $(n=12$, $92.3 \%)$ were found to be operated for emergencies $(p<0.01)$. Diagnostic and demographic characteristics of the operated COVID- 19 patients were given in Table 2. A total of 28 (14.4\%) patients were admitted to the ICU in the postoperative period. Although the rate of postoperative ICU stay was higher in those with COVID-19, the difference was not statistically significant $(n=4,30.8 \%$ vs. $n=24,13.2 \%$; $p>0.05)$.

Table 2. The diagnostic and demographic characteristics of SARS-CoV-2 (+) patients

\begin{tabular}{llccc}
\hline$\#$ & Diagnosis & Age & Gender & $\begin{array}{c}\text { Outcome } \\
\text { (Death) }\end{array}$ \\
\hline 1 & Appendicitis & 67 & Female & + \\
2 & Appendicitis & 67 & Male & - \\
3 & Appendicitis & 25 & Male & - \\
4 & Appendicitis & 62 & Male & - \\
5 & Appendicitis & 28 & Female & - \\
6 & Appendicitis & 31 & Female & - \\
7 & Appendicitis & 18 & Male & - \\
8 & Appendicitis & 37 & Female & - \\
9 & Appendicitis & 26 & Female & - \\
10 & Appendicitis & 31 & Male & - \\
11 & Strangulated femoral hernia & 82 & Female & + \\
12 & Perforated cholecystitis & 76 & Male & - \\
13 & Stomach cancer & 67 & Female & + \\
\hline
\end{tabular}

SARS-CoV-2: Severe acute respiratory syndrome coronavirus 2.
The median length of ICU stay was 5.5 days (range: I-60) in all patients and 6 days (range: $1-60$ ) in those who were negative; length of ICU stay was I day for all of those with COVID-I9 and stayed in ICU. No significant difference was found between the patients who tested negative and positive in terms of the length of hospital stay, which had a median of 2 days (range: $0-60$ ) for those who were negative and 2 days (range: $1-10)$ for those who were positive $(p>0.05)$.

Three patients with COVID-19 died on the Ist postoperative day (Table 2). Mortality was significantly higher in this group than in those who tested negative $(n=3,23.1 \%$ vs. $n=8,4.4 \%$; $\mathrm{P}<0.05$ ) (Table I). During the study, none of the healthcare workers in our clinic developed COVID-19 symptoms. Three patients who had elective surgery were found to be SARSCoV-2 (+) in the follow-up period after discharge.

\section{DISCUSSION}

Surgical clinics, one of the essential elements of the health system, adapted to the rapidly changing circumstances in all countries affected by the COVID-19 pandemic. In this process, necessary arrangements were introduced to continue performing emergency and non-deferrable elective operations in surgical clinics. It was necessary to continue such non-deferrable healthcare services and protect the well-being of healthcare workers who would provide these services and were at high risk of contagion. In a study conducted during the COVID-19 period in the emergency surgery clinics in Italy, it was observed that almost one surgeon was infected or put in protective quarantine in $33.8 \%$ of surgical teams. [7] In another study, it was pointed out that 708 healthcare workers died from COVID-19 worldwide until April 27, 2020; 365 (5I.5\%) of these were physicians, and I 26 (I7.9\%) were nurses. ${ }^{[8]}$ In our study, we investigated in which operations and age group the surgeons serving during the epidemic were under a greater risk. The patients who need a surgical 
operation for non-deferrable diseases such as malignancy, in particular, isolate themselves in preventive quarantine and constitute a lower risk in terms of infecting the surgical team. Patients who are younger, active, and in need of emergency operations are the leading risk group for surgical clinics. We believe that our study provides significant knowledge about the operations performed in general surgery clinics during the pandemic, postoperative follow-up of patients, and which operations and patient groups constitute a higher risk of transmitting the infection to the surgical team.

Our hospital was declared a specialized hospital for the care of COVID-19 patients by the Ministry of Health on March 20, 2020; after that, our clinics continued emergency and non-deferrable operations while serving COVID- 19 patients simultaneously. In that period, guidelines were published to describe the procedures that surgeons should follow from the time they meet patients with possible or confirmed COVID-19 diagnosis to their discharge from the hospital. ${ }^{[4,9]}$ In all guidelines, it was stated that each patient should be treated as possible COVID-19 patient, surgical team should use personal protective equipment to prevent droplet transmission, operations should be performed with the lowest number of staff possible in the operating room, the patients should be tested for SARS-CoV-2 before the operation, and asymptomatic patients should undergo thorax imaging. ${ }^{4,10]}$ Whether operations should be performed laparoscopically or by open method is controversial. Although previous studies indicated that laparoscopy might lead to aerosolization of blood-borne viruses, there is no evidence of this effect in COVID-19. [II] Following the guidelines, all patients in this study were tested for SARS-CoV-2 before the operations. The surgeries were performed with open surgical procedures with the necessary precautions in place.

In a multi-center study investigating the outcome of 34 patients operated on during the COVID-19 incubation period retrospectively, Lei et al. ${ }^{[12]}$ found that 15 (44\%) patients needed post-operative ICU stay and that the mortality was between $20 \%$ and $5 \%$. They concluded that surgeries performed during the COVID-19 incubation period might exacerbate the disease. In our study, the rate of ICU stay was $30.8 \%$ for patients with COVID-19. Among the COVID-19 patients, the mortality rate was $23.1 \%$, all of whom died on the $I^{\text {st }}$ postoperative day. That the patients were deceased in the early post-operative period suggests that the cause of death was related to COVID-19 rather than surgical complications.

It was found that most of the patients with COVID-19 had surgery due to acute appendicitis $(n=10,76.9 \%)$. Acute appendicitis is the most common emergency encountered by general surgeons and constitutes $4.5 \%$ of all cases of abdominal pain. ${ }^{[13]}$ Therefore, it is necessary to be more careful in cases requiring emergency surgical intervention such as appendicitis, severe bleeding, perforation, strangulated hernias, and trauma, which are frequently encountered and allow no time to perform a COVID-19 test.

A study in China indicated that $41 \%$ of 138 patients admitted to the hospital were found to get infected with SARS-CoV-2 at the hospital, and the hospitals were among the riskiest places for the spread of the infection. ${ }^{[14]}$ However, in a study Alimoglu et al., ${ }^{[15]}$ among 39 patients who had surgeries due to malignancies and did not have COVID-19 symptoms before the operation, none were found to have COVID-19 symptoms in the postoperative 15-day follow-up. Besides, none of the healthcare personnel involved in these surgeries were found to have COVID-1 9 symptoms. In our study, three patients were found to have the SARS-CoV-2 infection in the follow-up period after their discharge from the hospital. In the surgical team's follow-up, COVID-19 symptoms were not detected in any healthcare personnel. Liang et al. ${ }^{[16]}$ analyzed 2007 COVID- 19 patients and found that cancer patients had the highest rate of ICU stay and mortality. In our study, patients with malignancies $(n=73,73.7 \%)$ constituted the majority of those who had non-deferrable elective surgery. Our results suggest that with the necessary precautions, the surgical team can be protected, and patients can be operated safely with no disruption to surgical services during the pandemic. Likewise, we believe that patients with malignancies can be operated safely during the pandemic.

Our study has some significant limitations, such as a low number of patients and retrospective design. In addition, the fact that patients were in voluntary quarantine, not a compulsory one after hospital discharge makes it challenging to pinpoint the source of infection as in-hospital transmission during their hospital stay for those who were found to be SARS-CoV-2(+) in the follow-up period. Moreover, that only those who developed COVID-19 symptoms after hospital discharge were tested in the follow-up period might have led to the omission of those who were asymptomatic.

\section{Conclusion}

Maintaining functional surgery departments under challenging times, such as a pandemic, will continue to be an important aspect of health systems. The most crucial measure to achieve this is to prevent the surgical team from catching the disease. In this period when the pandemic is rapidly evolving, we believe that the results of this study will help reduce in-hospital transmission, help prevent disease transmission to healthcare personnel, and allow the members of the surgical teams to know in which patient group they will be at higher risk of infection during the operation. However, more complete results would be obtained through studies with a larger number of cases and longer follow-up times.

Ethics Committee Approval: This study was approved by the Kartal Dr. Lutfi Kirdar City Hospital Ethics Committee (Date: 08.07.2020, Decision No: 2020/5I4/I8I/I). 
Peer-review: Internally peer-reviewed.

Authorship Contributions: Concept: K.Ç.; Design: K.Ç.; Supervision: K.Ç.; Resource: Y.T.; Materials: Y.T.; Data: Y.T.; Analysis: Y.T., K.Ç.; Literature search: Y.T., K.Ç.; Writing: Y.T.; Critical revision: K.Ç.

\section{Conflict of Interest: None declared.}

Financial Disclosure: The authors declared that this study has received no financial support.

\section{REFERENCES}

1. World Health Organization. Coronavirus Disease (COVID-19) Dashboard. Geneva: World Health Organization; 2020. Available from: https://covid19.who.int. [Last accessed on 2020 Mar 14].

2. Zhu N, Zhang D, Wang W, Li X, Yang B, Song J, et al. A novel coronavirus from patients with pneumonia in China, 2019. N Engl J Med 2020;382:727-33. [CrossRef]

3. Brindle ME, Gawande A. Managing COVID-19 in surgical systems. Ann Surg 2020;272:e1-2. [CrossRef]

4. Gök AF, Eryılmaz M, Özmen MM, Alimoğlu O, Ertekin C, Kurtoğlu $\mathrm{MH}$. Recommendations for trauma and emergency general surgery practice during COVID-19 pandemic. Ulus Travma Acil Cerrahi Derg 2020;26:335-42. [CrossRef]

5. Karaca A, Ozmen M, Uçar A, Yasti A, Demirer S. General surgery operating room practice in patients with COVID-19. Turk J Surg 2020;36:15. [CrossRef]

6. Coimbra R, Edwards S, Kurihara H, Bass GA, Balogh ZJ, Tilsed J, et al. European society of trauma and emergency surgery (ESTES) recommendations for trauma and emergency surgery preparation during times of COVID-19 infection. Eur J Trauma Emerg Surg 2020;46:505-10.

7. Patriti A, Baiocchi GL, Catena F, Marini P, Catarci M. Emergency general surgery in Italy during the COVID-19 outbreak: First survey from the real life. World J Emerg Surg 2020;15:36. [CrossRef]

8. Beyazadam D, Alimoğlu O. Healthcare workers are losing their lives in the battle of COVID-19 all over the globe. Anatol Clin 2020;25:183-4.

9. Coccolini F, Perrone G, Chiarugi M, Di Marzo F, Ansaloni L, Scandroglio I, et al. Surgery in COVID-19 patients: Operational directives. World J Emerg Surg 2020;15:25. [CrossRef]

10. Kamer E, Çolak T. What to do when a patient infected with COVID-19 needs an operation: A pre-surgery, peri-surgery and post-surgery guide. Turk J Colorectal Dis 2020;30:1-8. [CrossRef]

11. Mowbray N, Ansell J, Horwood J, Cornish J, Rizkallah P, Parker A, et al. Safe management of surgical smoke in the age of COVID-19. Br J Surg 2020;107:1406-13. [CrossRef]

12. Lei S, Jiang F, Su W, Chen C, Chen J, Mei W, et al. Clinical characteristics and outcomes of patients undergoing surgeries during the incubation period of COVID-19 infection. EClinicalMedicine 2020;21:100331. [CrossRef]

13. Cervellin G, Mora R, Ticinesi A, Meschi T, Comelli I, Catena F, et al. Epidemiology and outcomes of acute abdominal pain in a large urban emergency department: Retrospective analysis of 5,340 cases. Ann Transl Med 2016;4:362. [CrossRef]

14. Yu J, Ouyang W, Chua ML, Xie C. SARS-CoV-2 transmission in patients with cancer at a tertiary care hospital in Wuhan, China. JAMA Oncol 2020;6:1108-10. [CrossRef]

15. Alimoglu O, Erol CI, Kilic F, Baysal H. Cancer surgery during the COVID-19 pandemic in Turkey. Int J Surg 2020;79:54-5. [CrossRef]

16. Liang W, Guan W, Chen R, Wang W, Li J, Xu K, et al. Cancer patients in SARS-CoV-2 infection: A nationwide analysis in China. Lancet Oncol 2020;21:335-7. [CrossRef]

\section{ORİIINAL ÇALIŞMA - ÖZ}

\section{COVID-19 salgını altında genel cerrahi uygulamaları:} İstanbul'da bir salgın hastanesinin deneyimi

\section{Dr. Yasin Tosun, Dr. Kenan Çetin}

İstanbul Kartal Dr. Lütfi Kırdar Şehir Hastanesi, Genel Cerrahi Kliniği, İstanbul

AMAÇ: Pandemi sürecinde genel cerrahi kliniklerinde elektif operasyonlar ertelense de acil travma, akut karın ve kanser ameliyatları gibi ertelenemeyen operasyonlara devam edildi. Çalışmamızda salgın süresince hastanemiz genel cerrahi kliniğinde ameliyat edilen acil ve ertelenemeyen elektif olguları sunmayı, pandemi sırasında bu hastalara müdahale eden sağlık çalışanları için asıl risk oluşturan genel cerrahi hasta grubunu belirlemeyi ve benzer bir durum yaşanma olasılığı için tecrübemizi paylaşmayı amaçladık.

GEREÇ VE YÖNTEM: Çalışma geriye dönük bir kohort çalışması olarak tasarlanmıştır. 10 Mart-23 Mayıs 2020 tarihleri arasında İstanbul Kartal Dr. Lütfi Kırdar Şehir Hastanesi'ne başvuran acil ve ertelenemeyen elektif ameliyata alınan hastalar çalışmaya dahil edildi. Hastalar ameliyat öncesi SARSCoV-2 enfeksiyonu açısından test edildi. Taburculuk sonrası da pansuman ve poliklinik takiplerinde rutin olarak ateş ve COVID-19 semptomları açısından kontrollerine devam edildi. Ayrıca ulusal sağılık takip sisteminden (e-nabız) taburculuk sonrası ilk I5 günde COVID-19 tanısı alıp almadığı kontrol edildi. Taburculuk sonrası ilk on beş günde COVID-19 sürüntüsü (RT-PCR) pozitif olan ya da çekilen toraks tomografisinde infiltrasyonu olan hastalar hastane bulaşı açısından şüpheli kabul edildi.

BULGULAR: 10 Mart-23 Mayıs 2020 tarihleri arasında COVID-19 salgını süresince çalışmamızda toplam 195 hasta ameliyat edildi. Bunların 96 'sı (\%49.2) acil, 99'u (\%50.8) ertelenemez elektif ameliyatlardı. Başvuru esnasında hastaların I3'üne COVID- I9 sürüntü (RT-PCR) ve toraks tomografi bulguları ile COVID-19 tanısı konuldu. Covid(+) ameliyat olan hasta grubunun büyük bir kısmının $(n=12, \% 92.3)$ acil nedenlerden ameliyat olduğu görüldü. Covid(+) grupta ameliyat sonrası birinci gün üç hastada mortalite saptandı. Mortalite oranları Covid(+) hastalarda istatistiksel olarak daha yüksekti $(n=3,23.1 \%$ ve $n=8,4.4 \%)$. Çalışma süresince kliniğimizdeki hiçbir sağlık çalışanında COVID-19 semptomu saptanmadı. Elektif ameliyat olan 3 hastada ise hastane yatış ve taburculuk sonrası takiplerinde COVID-19 pozitifliği saptandı.

TARTIŞMA: Bu zor zamanlarda ameliyatların sürmesi sağlık sistemimizin önemli bir yönü olmaya devam edecektir. Sonuçlarımızın hastane içi hastalık yayılımının azalmasında, sağlık personeline bulaşın engellenmesinde ve cerrahi ekibin hangi hasta grubunda yüksek risk altında olacaklarını bilmelerinde faydalı olacağına inanıyoruz.

Anahtar sözcükler: Acil operasyonlar; apandisit; COVID-19; genel cerrahi; SARS-CoV-2.

Ulus Travma Acil Cerrahi Derg 2022;28(2):175-179 doi: 10.14744/tjtes.2020.80025 